\title{
Systematic analysis of education
}

\section{Mahbuba ERGASHEVA ${ }^{1}$}

Samarkand State University

\begin{tabular}{l} 
ARTICLE INFO \\
\hline Article history: \\
Received June 2021 \\
Received in revised form \\
20 June 2021 \\
Accepted 25 July 2021 \\
Available online \\
25 August 2021 \\
\hline
\end{tabular}

\section{Keywords:}

system,

systems approach, systems analysis, modern education, synergetic methodology, science and education, theory and practice.

\begin{abstract}
Today, almost all regions of the world are governed by knowledge and intelligence. Today humanity is very advanced in science and education. In our information age, the prestige of intellectual professions is growing. Bringing a person to this potential, realizing his intellectual potential is the most important task of the education system. However, countries around the world see that the economies of countries with underdeveloped education are also underdeveloped. Today it is impossible to educate modern personnel without the introduction of a modern education system. The synergetic methodology is an important area that contributes to integrated education, which can become the basis of modern education based on a systems approach. The problem of a systems approach to modern education, promoted in the article, focuses on interdisciplinary integration, critical and logical thinking as part of synergistic education. This is an approach that corresponds to modern education, proving that it is constantly evolving, tirelessly working on itself and that stagnation in the learning process is unacceptable.
\end{abstract}

2181-1415/C) 2021 in Science LLC.

This is an open access article under the Attribution 4.0 International (CC BY 4.0) license (https://creativecommons.org/licenses/by/4.0/deed.ru)

\section{Таълимнинг тизимли тахлили}

\author{
Калит сўзлар: \\ тизим, \\ тизимли ёндашув, \\ тизимли тахлил, \\ замонавий таълим, \\ синергетик методология, \\ фан ва таълим, \\ назария ва амалиёт.
}

\begin{abstract}
АННОТАЦИЯ
Бугун дунёда деярли барча сохаларни билим ва ақл бошқармоқда. Бугун фан ва таълимда инсоният жуда илгарилаб кетди. Бугунги кунда ахборотлашган асрда интеллектуал касблар нуфузи тобора ортиб бормоқда. Инсонни бу салохиятга олиб келиш, унинг ақл имкониятларини рўёбга чиқариш таълим тизимининг энг мухим вазифасидир. Вахоланки таълими тараққий этмаган мамла-
\end{abstract}

\footnotetext{
${ }^{1} \mathrm{PhD}$, Samarkand State University, Samarkand, Uzbekistan,

E-mail: mahbuba_ergasheva@mail.
} 
катлар иқтисодиёти хам тараққий этмаганлигини бутун дунё мамлакатлари куцриб келяпти. Бугунги кунда замонавий таълим тизимини жорий этмасдан туриб, замон талабига мос кадрларни етиштириб бўлмайди. Синергетика методологияси тизимли ёндашув асосида айнан замонавий таълим учун асос бўла оладиган, интеграцион таълимни тарғиб этаётган мухим йўналишдир. Мақолада тарғиб этилаётган замонавий таълимга тизимли ёндашув масаласи синергетик таълимнинг бир қисми сифатида фанлараро интеграцияни, танқидий ва мантиқий тафаккурни, доимо ривожланиб боришни, ўз устида тинимсиз ишлашни, таълим жараёнида турғунликка йўл қўйиб бўлмасликни исботлаб берадиган замонавий таълимга мос келадиган ёндашувдир.

\section{Системный анализ образования}

\section{Ключевые слова:}

система,

системный подход, системный анализ, современное образование, синергетическая методология, наука и образование, теория и практика.

\begin{abstract}
АННОТАЦИЯ
Сегодня почти все отрасли мира управляются знаниями и разумом. Сегодня человечество очень продвинулось в науке и образовании. В наш информационный век престиж интеллектуальных профессий растет. Довести человека до этого потенциала, реализовать его интеллектуальный потенциал - важнейшая задача системы образования. Однако страны всего мира видят, что экономики стран со слаборазвитым образованием также недостаточно развиты. Сегодня невозможно воспитать современные кадры без внедрения современной системы образования. Методология синергетики - важное направление, способствующее интегрированному образованию, которое может стать основой современного образования, основанного на системном подходе. Проблема системного подхода к современному образованию, продвигаемая в статье, фокусируется на междисциплинарной интеграции, критическом и логическом мышлении как части синергетического образования. Это подход, который соответствует современному образованию, доказывая, что оно постоянно развивается, неустанно работает над собой и что стагнация в процессе обучения недопустима.
\end{abstract}

Бугунги кунда деярли барча сохаларда тизимли ёндашув, тизимли тахлил тушунчалари кириб келди. Тизимли тахлил, тизимли ёндашув масаласи мантиқий ва танқидий тафаккур тарзи билан боғлиқ бўлганлиги учун хам бугунги даврнинг энг долзарб масалалари сарасига киради. Бугун замонавий таълимсиз тараққиётга эришиш жуда мушкул. Бугун Ўзбекистон иқтисодиёти, таълими ривожланган мамлакатлар таълим тизимидан камида анча йиллар орқада қолиб кетгани тан олишимиз керак бўлган аччиқ хақиқатдир. “Юксалиш” умуммиллий харакатини Ўзбекистоннинг жахон рейтингларидаги ўрни хақида умумий маълумотига курра мамлакатимиз жахондаги 203 давлат орасида 2019 йилги таълим тизимининг таъсирини ўлчаш ва бахолаш буйича халқаро маълумотлар базасида 79-ўрин, 
Фаровонлик ва барқарор иқтисодий ривожланиш индекси бўйича 101-ўрин,Инсон тараққиёти индекси бўйича 105-ўриндақайд этилади [6]. Бугунги кунда (2021) таълим даражаси бўйича 71 ўринда, Қирзизистондан хам бир поғона пасдда турганлиги таълим сифати ва самарадорлигини ошириш учун янада катта куч, мехнат, янгича ёндашувлар зарурат эканлигини англатади. Бугун дунёда деярли барча сохаларни билим ва ақл бошқармоқда. Бугун фан ва таълимда инсоният жуда илгарилаб кетди. Бугунги кунда ахборотлашган асрда интеллектуал касблар нуфузи тобора ортиб бормоқда. Ген инженерияси, роботатехника, нанотехно-логиялар, космология, биотехнология ва бошқа кўплаб сохаларда шу қадар катта ютуқлар қўлга киритиляптики, инсонниг ақли шу қадар кенг имкониятга эгалиги ўз исботини топиб боряпти. Инсонни бу салохиятга олиб келиш, унинг ақл имкониятларини руёбга чиқариш таълим тизимининг энг мухим вазифасидир. Бугунги кунда замонавий таълим тизимини жорий этмасдан туриб, замон талабига мос кадрларни етиштириб бўлмайди.

Синергетика методологияси тизимли ёндашув асосида айнан замонавий таълим учун асос бўла оладиган, интеграцион таълимни тарғибэтаётган мухим йўналишдир. Бугун дунёда таълим жараёни шу қадар илгарилаб кетдики, энди ривожланган мамлакатлар хеч бир қўшимча моддий ва табиий ресурсларни сарфламасдан, хеч бир инергияни ишлатмасдан фақат ақл билан юксак иқтисодий салохиятга эриша оляпти. Биргина мисол, иқтисодий ўсиш даражаси энг ривож-ланган мамлакатлардан бири саналадиган АҚШ нинг 1980 йилдан 2010 йилга қадар иқтисодий ўсиш кўрсаткичлари схемасига қарасак, ундаги эътиборимизни тортган жихат шу бўлдики, ушбу мамлакат 1980 йиллардан бошлаб деярли хеч бир энергия сарфламасдан туриб хам ЯИМ хажми буйича, яъни бойлик даражаси бўйича ўсиб бораверган [8]. Бунинг асосий сабаби эса фақат ақл ва билимдир. Демак бугунги кунда замонавий таълимни тўғри йўлга қўйиш орқали жуда катта куч ва мехнат сарфламасдан туриб хам иқтисодий юксалишга эришиш мумкин. Ўзбекистон Президенти ташаббуси билан 2019 йилдан бошлаб республикамизда замонавий таълим бериш мақсадида жуда кўплаб ислохотлар амалга оширилди. Масалан, Президент мактаблари, ихтисослаштирилган мактаблар, хусусий таълим муассасалари, олий таълим тизимидаги ислохотлар ва хоказо.

Таълимда синергетик қонуниятларни намоён бўлиши, аввало, фанлараро интеграцион билим берилишида акс этмоқда. Бугунги кунда таълим тизимимизда "STEAM фанлар", “STEAM фанлар"ни чукурлаштириб ўтилиши каби масалалар кириб келди. "STEAM фанлар" нима? “STEAM фанлар” ни ўқитиш назарияси деганда қанақа ўқитиш назарда тутилади? деган савол туғилиши табиийдир. STEAМ инглизча сўзларнинг бош харфлари қисқартмаси, яъни:

Science - илм-фан

Technology - технология

Engineering - мухандислик

Arts - санъат

Mathematics - математика

“STEAM фанлар” бу айнан бир неча фанларни интеграцион уйғунлигидан ташкил топган, назария ва амалиётни бирлаштирган, таълим жараёнида амалий ёндашувни қўллайдиган мантиқий умумлашмадир. Аслида Ўзбекистон халқи, мутафаккирлари азалдан кўпгина сохаларни мантиқий уйғунликда ўрганишга, тафаккур қилишга харакат қилиб келган. Бизнинг алломаларимиз, айниқса, ўрта аср шарқ мутафаккирларининг барчаси қомусий билим эгалари бўлганлиги бунга мисолдир. Демак биз тарғиб этаётган замонавий таълимга тизимли ёндашув синергетик таълимнинг бир қисми сифатида фанлараро интеграцияни, танқидий ва мантиқий тафаккурни, доимо ривожланиб боришни, ўз устида 
тинимсиз ишлашни, таълим жараёнида турғунликка йўл қўйиб бўлмасликни исботлаб берадиган замонавий таълимга мос келадиган ёндашувдир.

Аввало шуни таъкидлаш ўринлики, таълим жараёни хам яхлит бир система сифатида тизимли тахлил объекти бўла олади. Тизим тушунчасига кўплаб илмий, фалсафий адабиётларда таъриф берилган ва барчасининг мохияти ўзаро умумий характерга эга. Тизим - бу элементлардан ташкил топган объект ёки объектлар йиғиндиси. Тизим - бу ўзаро боғлиқ ва тартиблаштирилган элементлардан ташкил топган, ягона мақсад сари интилувчи объект ёки объектлар йиғиндиси. Тизим - хар бири алохида вазифаларни бажарувчи, ягона мақсадга йўналтирилган, ўзаро боғланган, бошқарилувчи элементларнинг муайян тузилмага эга бўлган мажмуаси. Бу таъриф мураккаб тизимларга хос таърифдир. Бизга айнан мана шу таъриф кўпроқ мос келади ва жамиятда ўрганишни талаб қиладиган объектлар айнан мураккаб тизимлардир [7]. Биз тадқиқ этаётган таълим жараёни хам айнан мураккаб тизим хисобланади. Таълим жараёнини синергетик қонуниятларга эга бўлган мураккаб тизим сифатида талқин эта оламиз. Таълим жараёни - бу мураккаб тизимдир, чунки у ўзаро боғлиқ ва ўзаро тузилмалаштирилган элементлардан ташкил топади: мактабгача таълим, умумий ўрта таълим, ўрта махсус касб-хунар таълими, олий таълим, таълим берувчи, таълим олувчи ва х.к. Бу элементлар ўзаро иерархик тартибда бирлашган ва ягона мақсад сари интилади, шу мақсадни амалга ошириш учун зарурий функцияларни бажаради. Аммо шуни хам инобатга олиш лозимки, бугунги кунда таълим жараёнига хақиқатдан хам бир бутунликда ривожланадиган, ундаги хар бир элементнинг ривожи бутун бир тизим ривожи учун мухим хисобланадиган тизим сифатида ёндашиляптими?; Ёки бу тизимдаги хар бир элемент ўзича харакатланяптими?; Балки Ўзбекистондаги таълим жараёнига хали хам яхлит бир бутун тизим сифатида қаралмагани учун хам ягона бир миллий таълим тизимига эришиш қийин кечаётгандир. Таълим тизими деймиз, лекин хақиқатдан хам бугун таълимга тизим сифатида қараляптими?; Хақиқатдан хам унинг таркибига кирувчи хар бир элемент биргаликда ислох этиляптими?; Таълим даражасини оширишда хамда сифатини таъминлашда таълим жараёнининг хар бир буғини биргаликда, хамкорликда харакат қиляптими? Бу каби саволлар жуда кўп ва бу саволлар жавобини топиш хам ўз кўлимизда деб хисоблаймиз. Таълимда биргина олий таълимни ёки, ўрта таълимни, ёхуд мактабгача, касбий таълимни ислох этиб натижага эришиб бўлмайди. Хар қандай ислохот кўлланилганда таълимнинг куйи босқичидан юқорига қадарўз босқичига мостарзда қўлланилсагина самарадорликка эришиш мумкин. Мисол учун олий таълим тизимида кейинги йилларда бир қанча замонавий ислохотлар кириб келди. Модулли ўқитиш, масофавий ўқитиш, бахолашдаги ўзгаришлар ва хоказо. Бу инновациялар жахон талаби, жуда яхши, аммо бу инновациялардан умуман хабардор бўлмаган талаба то тушуниб олгунича камида 1 йил вақт ўтиб кетмоқда, сиртқи таълимда ўқиётган талабалар бутунлай тушуна олмасдан, хаттоки, ўқишни тугаллаб куйиш холатларига гувох бўлмоқдамиз, буни тан олишимиз, ечим топишимиз лозим. Бизнингча, инновацияни қўллашда юқорида айтганимиздек хар бир таълим босқичида ўзига мослаштириб, элементар тарзда бирваракайига қўлланса, у интеграцион таълим бўлади, олий таълимга кириб келган талаба методни ўзлаштиришга ёки инновацияни тушуниб олишга вақт сарфламасдан ўз мутахассилигини ўрганишга кўпроқ эътибор қаратади. Мақсад, таълим жараёнига хақиқий бир бутун система сифатида қараш.

Хар бир тизим, аввало, яхлитлилик хусусиятига эга. Яъни тизимнинг яхлитлиги шундаки, унинг тизим сифатидаги мохияти алохида қисмларга бўлинганда йўқолади. Масалан, олий таълим дейиганда биз юқори малакали кадрларни тайёрлайдиган маълум бир системани тушунамиз. Уни қисмларга бўлганда эса (яъни педагог, талаба, кафедра, факультет, 
ректорат ва хк) унинг яхлитликхусусиятига путур етади ва тизим сифатидаги мохияти инкор этилади.

Тизим ўзаро боғлиқлилик хусусиятига эга. Яъни маълум бир мураккаб тизимни ташкил этган элементлар, қисмлар уззаро бохлиқликда тизим тараққиёти учун кучли таъсирга эга бўлиши лозим. Бунга мисол қилиб таълим жараёнининг тараққиёти биргина олий таълим, ёки ўрта таълимга эмас, балки, таълим тизимини ташкил этувчи хар бир элемент ривожига, хар бир таълим босқичи тараққиётига боғлиқлигин келтириш мумкин.

Тизимнинг мақсадга йўналтирилганлик хусусиятига - тизим ва унинг қуйи тизимларининг ягона мақсадга йўналтирилганлиги назарда тутилади. Масалан, олий таълим ва уни ташкил этувчи элементлар ягона мақсадга интилади - юқори малакали мутахассисларни тайёрлаш.

Тизимнинг тузилмавийлик хусусияти дейилганда - тизимни ташкил этувчи элементлар, қисмларни ўзаро бирор қонун қоидага мувофиқ ташкил этилганлигини тушуниш мумкин. Масалан таълим жараёнининг ташкил этилиши маълум бир жамиятдаги, мамлакатдаги ўзига хос қонун қоидаларга асосланган холда ташкил этилади.

Тизимнинг натижавийлик (самарадорлик, фойдалилик) хусусияти тизим-нинг мавжуд бўлиш шартларидан биридир. Агар тизим натижа бермаса, тизим бутунлай йўқ бўлиб кетади ёки бундай тизимнинг мавжудлиги фақатгина ортиқча сарф-харажатга олиб келади, бефойда хатти-харакатлар бўлиб қолади. Таълим жараёнида бу хусусият энг мухим хусусиятлардан бири хисобланади. Хар бир таълим босқичи, албатта, натижавийлик хусусиятига эга бўлиши заруратдир. Таълим тизимининг натижавийлик хусусияти унинг келажагини, ривожини таъминлаб, тараққиёт учун хизмат қилиши билан белгиланади.

Таълим тизимининг ўзи хам бутун бир ижтимоий тизимнинг энг мухим турларидан, элементларидан бири саналади. Таълим ижтимоий тизимнинг ажралмас элементи сифатида - инсонларга ва ёш авлодга таълим ва тарбия бериш, таълим жараёнини ташкил этиш ва бошқариш мақсадларига хизмат қилувчи турли структуравий ва функционал боғлиқ бўлган компонентлар мажмуидан иборат бўлади.

Тахлил нима? Тахлил тушунчаси қуйидаги таснифларга эга:

1. Нарса, ходиса ва шу кабиларни мохият, қонуният ва бошқа жихатлардан текшириш, уррганиш иши;

2. Бирор нарса, маълумот ва шу кабиларни маълум нуқтаи назардан ўрганиш, бахолаш;

3. Бирор нарсанинг таркибини белгилаш ва унинг мохиятини тадқиқ этиш [7].

Демак таълим жараёнини тизимли тахлил этганда, аввало, уни яхлит, ўзаро боғлиқликдаги элементлардан ташкил топган мураккаб тизим сифатида қараймиз. Кейин ушбу мураккаб тизимнинг қонуниятларини, мохиятини текширамиз (тахлил этамиз), таълим тизимига маълум нуқтаи назардан ёндашамиз (масалан синергетик) хамда таълимнинг мохиятини янгича усулда тадқиқ этамиз.

Тахлилнинг нисбатан мукаммал тури сифатида тизимли тахлил алохида ўрин тутади. Тизимли тахлил - бу бир қанча фанлар (математика, кибернетика, синергетика ва х.к.) негизида хосил бўлган илм сохаси хисобланади ва ўрганила-ётган объектнинг тизимли масалаларини аниқлаш, уларни тасаввур этишда моделлаштиришдан фойдаланиш, шулар асосида турли алтернатив йўллар (қарорлар)ни шакллантириш хамда улар асосида оптимал вариантни танлашга ёрдам берувчи билимларни узз ичига жамловчи соха хисобланади. Тизимли тахлил деб, мураккаб хисобланган ижтимоий, сиёсий, харбий, иқтисодий, илмий характерга эга бўлган масалаларни ўрганиш учун қўлланиладиган тахлилий воситалар (усуллар) ёрдамида амалга ошириладиган тахлил турига айтилади [7]. 
Тизимли тахлилнинг ривожи XX аср ўрталарида пайдо бўлди. Бунда асосий ўринни мураккаб объектларни тахлил этиш, билиш ва амалий тадбиқ этиш жараёнлари эгаллади. Тизимли тахлил мустақил тадқиқот йўналиши сифатида 1950-1960 йилларда АҚШда қуролли кучларни техник жихатдан ривожлантириш, космосни ўзлаштириш, давлат бошқаруви аппаратини такомиллаштириш, ишлаб чиқариш қувватларини тақсимот қилиш, ишчи кучи ва ускуналарга бўлган талабни белгилаш, турли махсулотларга эхтиёжларни аниқлаш каби йирик бизнес вазифаларини бажаришда қўлланилган. Замонавий маънодаги тушунча шаклида тизимли ёндашув ривожи икки йўналишда - назарий ва амалий шаклда параллел равишда олиб борилмокда. Назарий йўналишда турли концепциялар изчиллик билан жиддий ўрганиладиган тизимга бирлашиб, мустақил илмий соха - тизим назарияси пайдо бўлади [7]. Тизим назарияси тўғрисидаги мумтоз асарлар сирасига австриялик биолог Людвиг Фон Берталанфи (1901-1972) ва унинг издошлари асарларини киритиш мумкин. Ушбу соханинг энг кўзга кўринган вакиллари сифатида А. Пуанкаре, А.Богданов, А. Колмогоров, В. Арнолд, И. Пригожина, Р. Акофф, Э. Ласлони киритиш мумкин.

Тизимли тахлил жараёнида муайян тахлил этилувчи тизим атроф-мухитдан ажратилиб олинади, унинг таркиби аниқланади, тузилмалар, функциялар, интеграл хусусиятлар, шунингдек тизимни ташкил этувчи омиллар ва атроф-мухит билан муносабатлар тахлил этилади. Тизимли ёндашув объектлар тўпламларига, алохида объектлар ва уларнинг таркибий қисмларига, шунингдек объектларнинг хусусиятлари ва ажралмас хусусиятларига нисбатан қўлланилади. Масалан, олий таълимда бериладиган замонавий таълим жараёни ёки умумий ўрта таълим тизими тадқиқот объекти сифатида ажратиб олиниб ундаги муаммолар, ютуқлар ва камчиликлар, тизимни ташкил этган элементлар фаолияти ва хоказо барча қисмлари алохида ўрганилади, мукаммал тахлил этилади ва тахлил натижасида умумий, назарий, амалий хулосага келинади.

Республикамизда бугунги кунга келиб талаба ёшларни қўллаб қувватлаш, хатто, талабалар турар жойлари, ижара масаласигача давлат сиёсати даражасида уй̆ланаётгани бежизга эмас [1]. Бундай ислохотдар жуда кўп амалга оширилмоқда. Асосийси, барча харакатлар таълим ривожига қаратилмоқдаки, уларни қабул қилишда, англаб етишда бироз сусткашликка йўл қўйилаяпти, назаримизда.

$\mathrm{XX}$ асрнинг ўрталаридан бошлаб тизимли ёндашув ва тизимларнинг умумий назарияси сохасида ривожланиш давом этмоқда. Тизимли ёндашув замонавий фан ва амалиётнинг мухим услубий принципларидан биридир. Тизимли ёндашув усуллари кўплаб назарий ва амалий муаммоларни хал қилишда кенг қўлланилади.

Тизимли ёндашувда тахлил қилинадиган объект маълум бир элементлар тўплами сифатида кўриб чиқилади, уларнинг ўзаро боғлиқлиги ушбу тўпламнинг ажралмас хусусиятларини аниқлайди. Асосий урғу ўрганилаётган объект ичига, унинг ташқи мухит ва атроф-мухит билан ўзаро муносабатларига, юзага келадиган боғланиш ва алоқаларни аниқлашга қаратилган. Таълим жараёнига тизимли ёндашганда, асосий урғу ўрганилаётган объектга, яъни маълум бир таълим босқичига (масалан, олий таълим) қаратилади ва уни ташқи олам ва атроф-мухит билан алоқадорлиги, тизим сифатида ташқаридан маълумотларни қабул қилиши ва ўз навбатида ташқи оламга ўзидан ахборотларни чиқариши каби хусусиятлари тахлил этилади.

Таълим жараёнига тизимли ёндашувни қўллашнинг мухимлиги шундаки, таълим очиқ тизим бўлганлиги учун хам, мазкур жараённи инновациялар ва билимлар, миллий ва умуминсоний тажрибалар асосида энг яхши ташкил этишга имкон беради. Интеграциялашган ёндашув мазкур жараённинг ички ва ташқи мухитини хисобга олишни ўз ичига олади. Бу шуни англатадики, замонавий таълим жараёнида, нафақат ички, балки ташқи 
омилларни - ижтимоий, сиёсий, маънавий, маърифий, иқтисодий, геосиёсий, демографик, экологик ва бошқа омилларни хам хисобга олиш кераклиги билан изохланади. Бу омиллар замонавий таълимни тахлил қилишда мухим жихатлардир. Мисол учун, кўп холларда, жамиятда янги ижтимоий тизим хосил бўлганда, таълим ислохотлари амалга оширилганда, янги ғоялар, инновациялар кириб келгандахудди шу каби мухит шаклланади ва бу шаклланиш босқичида, албатта ташқи ва ички омиллар таъсири хисобга олиниши шарт.

Тизимли тахлил дейилганда бир қатор фанларни, операцияларни, ижтимоий-сиёсий жараёнларни тадқиқ қилишни, мақбул бошқарув назариясини, шунингдек, тизимлар назариясини ва тизимларнинг ишлашини ташкил этиш назарияси усулларини ва бошқа тизимлар тахлилига алоқадор назарияларни тушуниш мумкин. Белгиланган вазифаларни муваффақиятли хал қилиш учун тизимли тахлил назарий ва амалий йўналишларнинг умумийлигидан фойдаланади. Бугунги кунда тизимли тахлил кўплаб сохаларда,жараёнларда уз муаммоларини аниқлаб, тахлил этишда самарали тадқиқот методологияси сифатида қўлланиб келинмоқда. Шу ўринда айтиш лозимки, тизимли тахлил алохида илмий тайёргарликни, турли илмий услубларни мақсадли танлаш ва ўринли қўллаш, ўрганилаётган муаммо бўйича билимга эга бўлишни талаб этувчи фаолиятнинг мураккаб туридир.

“Тизимли тахлил” атамаси биринчи марта 1948 йилдаRAND корпорацияси ишида ташқи менежмент вазифалари билан боғлиқ холда пайдо бўлган. Машхур рус олими А.А. Богданов ўзининг мулохазаларини илк бор тизимли ёндашув асосида баён қилган ва шу тариқа тизимлар назарияси фани яратилишига асос солган. У хар қандай жараён ёки объект муаян ташкиллаштирилганлик даражасига эга бўлиши тўғрисида гипотезани олға суради ва барча ходисаларни ташкиллаштириш ва парчаланиш жараёнлари сифатида кўради: олимнинг фикрича, объект элемент-ларининг интегративлик даражаси юқори бўлса, унинг ташкиллаштирилганлик даражаси хам юқори бўлади [2]. Людвиг фон Берталанфи (19011972) мураккаб тизимлар назариясига биринчи бўлиб асос солди. У мураккаб тизимларнинг умумий хусусиятларини таърифлашга муваффақ бўлди. У содда ва мураккаб тизимлар хусусиятларини алохида ўрганиб чикди. У содда тизимлар ташқи мухитга нисбатан ёпиқ бўлиши ва, аксинча, мураккаб тизимларнинг ташқи мухитга нисбатан очиқ эканлигини кўрсатиб бера олди [3].

Тизимлар назарияси - аслида тизимлар тўғрисидаги фан, тизимли тахлил эса тизимларни ўрганиш методологиясидир. 70 йиллар охирида мураккаб тизимлар назариясининг "синергетика" деб ном олган янги йунналиши пайдо бўлди. Ушбу тушунчани 1977 йилда илк бор машхур олим Герман Хакен ўзининг синергетика фанини асослаб беришга бағишланган асарида таърифлаб берди.

Демак, замонавий таълим жараёнининг тизимли тахлилидейилганда, мураккаб тузилмавий асосга эга бўлган таълим системасининг назарий, методологик, илмий, фалсафий, иқтисодий, ижтимоий, сиёсий, маънавий, хукуқий таркибга эга бўлган масалаларини, муаммо ва камчиликларини ўрганиш учун қўлланиладиган тахлилий усулларга айтилади. Биз ўз тадқиқотимизда бу жараёнда тизимли ёндашувга асосланган синергетик усулларни кўллашни тавсия этмоқдамиз.

Вахоланки, айнан тахлилий ёндашув (диссертация, монография, илмий мақола, шарх, хисобот, маълумотнома, тақриз ва бошқа шу шаклдаги манба ва хаттоки ижтимоий тизимлар, шу жумладан таълим тизими бўлиши мумкин) асосидагина соха вакиллари стратегик мазмунга эга бўлган масалаларни мазмун-мохиятини изохлаб, ижтимоий, иқтисодий, маданий ва сиёсий сохалар тараққиёти-ни таъминлашнинг асосий вазифаларини белгилаб беради. Тизимларни тахлил қилиш бу мураккаб техник, табиий ва ижтимоий тизимларни 
ўрганиш методо-логиясини умумлаштирадиган фанлараро тадқиқот усулидир. Н.Н. Моисевнинг ёзишича, тизимни тахлил қилиш - бу компьютерлардан фойдаланишга асосланган ва мураккаб тизимларни - техник, иқтисодий, экологик ва бошқаларни ўрганишга қаратилган усуллар тўплами[4].

Замонавий таълим жараёнида тизимли ёндашувни қўллашнинг ўзига хос кучли ва заиф томонларини фарқлаш мумкин.

Тизимли тахлилнинг кучли томони шундаки, - у доимий равишда муайян бир эхтиёжларлардан келиб чиқади, амалиётга таъсир этади, тадқиқот объектлари доирасини доимий равишда кенгайтириб боради ва жамиятнинг реал эхтиёж-ларидан четда қола олмайди. Бугун айнан таълим жараёни ривожи, тараққиёти ва шу орқали моддий фаровонликка эришиш масаласи бутун бир жамиятимиз асосий эхтиёжига айланганини бунга мисол қилиш мумкин.

Тизимли тахлилнинг заиф томони шундаки - ушбу тахлил усули баъзида хали шаклланиб улгурмаган, тизимни тадқиқ этишнинг етарлича ривожланмаган усулларидан фойдаланиш натижасида қарор қабул қилади ва бу ўз навбатида хақиқий муаммоларни эътиборсиз қолдиришга олиб келади. Бу каби холатлар тадқиқ этиш жараёнида учраши мумкин, аммо изчиллик ва тадрижийлик асосида кейинчалик ечим топиб кетиши мумкин.

Тизимли тахлилнинг якуний мақсади, тизим тадқиқотлари объекти (маълум бир ташкилот, жамоа, корхона, алохида минтақа, ижтимоий тузилма ва бошқалар) да юзага келган муаммоли вазиятни хал қилишдан иборатдир. Бугун жамияти-мизда таълим тизимидаги муаммоларни хал этилишида айнан тизимли ёндашув қўлланилиши мақсадга мувофиқдир. Вахоланки, тизимли тахлил муаммоли вазиятни ўрганиш, унинг сабабларини аниқлаш, уни хал қилиш йўлларини ишлаб чиқиш, қарор қабул қилиш ва муаммоли вазиятни хал қиладиган тизимнинг кейинги фаолиятини ташкил этиш билан шуғулланади. Хар қандай тизимни тадқиқ қилишнинг дастлабки босқичи бу тизимни тахлил қилиш объектини аниқлашдан бошланади. Ушбу босқичда тизимли тахлил методологиясини бошқа фанлар методологиясидан тубдан ажратиб турадиган вазифалар пайдо бўлади. Аввало, тахлил этилаётган оъектнинг мақсади ва амал қилиш доираси, қонуниятларини инобатга олиш лозим бўлади. Яъни замонавий олий таълимнинг мақсади, қайси доирада амал қила олиши, фаолияти, ваколатлари, қонуниятлари, низом ва меъёрий хужжатлари, функциялари тахлил этилиб, бу тахлил асосида қарор қабул қилиш учун турли кўринишга эга бўлган манбалар тайёрланади. Бу манбалар маъруза, тезис, хисобот, тавсиянома, меъёрий хужжат, қарор лойихаси, йиғилиш баённомаси ва бошқа шаклларда хам бўлиши мумкин. Жамият хаётида, шу жумладан таълим тизимида эса турли қонунлар, қарорлар, кодекслар, маънавий ва ахлоқий принципларни ишлаб чиқилиш жараёнларини тушуниш мумкин.

\section{Замонавий таЂлим жараёнига тизимли тахлилнинг асосий вазифалари:}

Бир қанча хорижий ва юртимизда нашр этилган тизимли тахлилга бағишланган манбаларда тизимли тахлилнинг бир қатор вазифалари кўрсатиб ўтилган. Жумладан:

Тизимли тахлилнинг бошқарувчанлик функцияси - бошқарув жараёнини турли босқичларида қарор қабул қилишга тайёргарлик кўриш, қарор қабул қилиш, қарорни жорий этиш ва қарор ижросини назоратини амалга ошириш учун ахборот билан таъминлайди. Таълим жараёнида бу функция таълим олувчи ва таълим берувчи манфааатлари ва эхтиёжларидан келиб чиққан холда муайян бир назарияларни, методологяларни, иннновацияларни ишлаб чиқилиши ва хаётга тадбиқ этилишида мухим ўрин тутади.

Тизимли тахлилнинг диагностик функцияси - жараённи кечиши ёки фаолият даовомида юзага келган холат (вазият), яъни жорий холат хақида объектив тасаввур(манзара)ни шакллантиради (тасвирлайди). Айнан, таълим тизимининг бугунги 
ахволи, хар бир таълим босқичининг ривожланишидаги ютуқ ва камчиликлар, таълим сифати, самарадорлиги, дун' рейтингидаги ўрни масала-ларини ёритишда соха вакиллари ушбу вазифага таянади.

Тизимли тахлилнинг огохлантирувчи функцияси-жараённи кечиши давомида вужудга келиши мумкин бўлган эхтимолий муаммо, турли шакл ва кўринишдаги хавф ва низолар хақида огохлик бериб, уларни баратараф этиш учун (уларга конструктив тус бериш учун) хизмат қилади. Бу функция таълим тизимида жуда мухим хисобланиб, соханинг келажагини олдиндан кўра билиш махоратини англатади.

Тизимли тахлилнинг билиш - ментал функцияси, фаолият давомида юзага келган холатнинг мохиятини англаш учун, бошқарувни амалга оширишда қўлланилаётган усулларни, ёндашувларни, қадриятларни, бир сўз билан айтганда бошқарув менталлигини ўзгартириш учун хизмат қилади.

Замонавий таълим жараёнига тизимли ёндашув назарий-методологик, илмийпедагогик, илмий-касбий мазмун бериб, таълим жараёнининг самара-дорлигини ошириш учун хизмат қилади. Бу ўз навбатида таълим-тарбия сохасида баркамол шахс тарбиясини амалга ошириш учун зарурий чора-тадбирларни ишлаб чиқиш ва амалиётга жорий этиш, фан-техника ютуқларини таълим-тарбия жараёнига жорий этиб, жахон талабларига жавоб берадиган мутахассислар тайёрлаш, таълим-тарбия тизимини миллий эхтиёж ва манфаатлардан келиб чиққан холда фаолиятни такомиллашувини тақозо этади.

Замонавий таълим жараёнига тизимли ёндашувнинг зарурияти шундаки, ушбу тахлил усулибугунги кунда сохада самарали тадқиқот усулларини ишлаб чиқилишида ва жамланишида, шу билан бир қаторда амалда қўлланишида мухим ахамият касб этади. Таълим жараёнини билишда, унинг хусусиятлари, жамият ривожи учун ахамиятлилик даражасини аниқлашда, тизимни ташкил этган хар бир таълим босқичи ёки бошқариладиган қуйи системаларни келажагини прогноз қилишда амалий ахамиятга эга бўлган тадқиқот усулидир.

Айтиш жоизки, тизимли тахлилда нафақат тизимнинг ўзи, балки унинг қуйи тизимлари хам яхлит холатда ўрганилиши лозим. Замонавий таълим жараёнига тизимли ёндашувнинг зарурати, у мазкур сохадаги бугунги кунда тобора долзарб бўлиб бораётган муаммоларни аниқлаш, тахлил этиш, уларга қарши қаратилган таълим ва тарбия нинг инновацион усулларини ишлаб чиқишда мухим вазифа-ларни амалга оширади. Шу билан бирга тизимли тахлил натижасида таълим тараққиёти, ривожи учун конструктив хусусиятига эга бўлган фикрлар, ғоялар шаклланади. Таълим тизимижамиятда инсоннингўзўзини ташкиллаштиришида, яъни ўз-ўзини тарбиялаши, асраши, сақлаши, химоя қилиши, умуман, одамзотни ўз-ўзидан хар томонлама ташкиллаша олишига алохида уринга эга. Хар бир ақли расо одам ўз хаёти давомида таълим тизими билан ўзаро боғлиқликда умр кечиради. Инсонннинг таълим орқали ўзини-ўзи онгли фаолият ва эзгу мақсадлар билан ташкил этиши фақат ўзига боғлиқ эканлигини таъкидлаш мумкин. Демак оқилона таълим кафолатланган келажак учун потенциал хисобланади [5].

Хулоса қилиб мулохаза юритадиган бўлсак:

Биринчидан, замонавий таълимга тизимли ёндашув бугунги кунда барча таълим босқичларини интеграцион фаолиятини амалга оширишда мухим саналади. Таълим жараёнидаги асосий муаммоларни аниқлаб, уларнинг бошланғич нуқта-сини топади ва ечимларини таклиф этади.

Иккинчидан, тизимли ёндашув таълим жараёнида хар бир инновацияни қўллашда танқидий ва мантиқий тафаккур асосида ёндашиб, миллий таълим тизимига мослаштиришда назарий ва амалий тавсиялар ишлаб чиқади. 
Учинчидан, замонавий таълимга тизимли ёндашув бугунги замон талабига мос келадиган таълим тизимини ишлаб чиқиш, ривожланган мамлакатлар таълимини импорт қилишда тахлилий ёндашиш хамда миллий таълим тизимига жорий этишда энг асосий ва мухим ёндашув хисобланади.

\section{ФОЙДАЛАНИЛГАН АДАБИЁТЛАР РЎЙХАТИ:}

1. Вазирлар Махкамасининг 2021 йил 11 мартдаги 132-сон қарори.

2. А.А. Богданов. Тектология: всеобщая организационная наука. Издание третье, заново переработанное и дополненное. - М., 1989. // Электронная публикация: Центр гуманитарных технологий. - 07.10.2010. URL: https://gtmarket.ru/ library/basis/5909.

3. Л. Фон Берталанфи. Общая теория систем: критический обзор. В сборнике переводов Исследования по общей теории систем. М.: - Прогресс, 1969. - С. 520.

4. Моисев Н.Н. Математические задачи системного анализа. М.: - Наука, 1981. - С. 488.

5. Ergasheva M.X. The role of the educational system in the process of self-organization of an individual Turkish Journal of Physiotherapy and Rehabilitation; 32(3) ISSN 2651-4451 | e-ISSN 2651446X.

6. https://xs.uz/uzkr/post/ozbekiston-dunyo-reytinglarida-qanday-orinlarda-bormoqda.

7. http://staff.tiiame.uz/storage/users/269/books/DNDYvlsSx4aq6im7COBpCzeFPDgMiPalg gmRGg94.pdf.

8. https://energycentral.com/c/ec/decoupling-energy-carbon-and-gdp-united-states. 